\title{
Correction to: MongoDB Vs PostgreSQL: a comparative study on performance aspects
}

\author{
Antonios Makris ${ }^{1} \cdot$ Konstantinos Tserpes ${ }^{1} \cdot$ Giannis Spiliopoulos $^{2} \cdot$ Dimitrios Zissis $^{2,3}$. \\ Dimosthenis Anagnostopoulos ${ }^{1}$
}

Published online: 25 September 2020

(C) The Author(s) 2020

\section{Correction to: Geoinformatica \\ https://doi.org/10.1007/s10707-020-00407-w}

The article "MongoDB Vs PostgreSQL: A comparative study on performance aspects", written by Antonios Makris, Konstantinos Tserpes, Giannis Spiliopoulos, Dimitrios Zissis, Dimosthenis Anagnostopoulos, was originally published electronically on the publisher's internet portal on 05 June 2020 without open access. With the author(s)' decision to opt for Open Choice the copyright of the article changed on 03 September 2020 to $($ ) The Author(s) 2020 and the article is forthwith distributed under a Creative Commons Attribution 4.0 International License, which permits use, sharing, adaptation, distribution and reproduction in any medium or format, as long as you give appropriate credit to the original author(s) and

The online version of the original article can be found at https://doi.org/10.1007/s10707-020-00407-w

Antonios Makris amakris@hua.gr

Konstantinos Tserpes

tserpes@hua.gr

Giannis Spiliopoulos

giannis.spiliopoulos@marinetraffic.com

Dimitrios Zissis

dzissis@ aegean.gr

Dimosthenis Anagnostopoulos

dimosthe@hua.gr

1 Department of Informatics, Telematics, Harokopio University of Athens, Athens, Greece

2 MarineTraffic, London, UK

3 Department of Product and Systems Design Engineering, University of the Aegean, Syros, Greece 
the source, provide a link to the Creative Commons licence, and indicate if changes were made. The images or other third party material in this article are included in the article's Creative Commons licence, unless indicated otherwise in a credit line to the material. If material is not included in the article's Creative Commons licence and your intended use is not permitted by statutory regulation or exceeds the permitted use, you will need to obtain permission directly from the copyright holder. To view a copy of this licence, visit http://creativecommons.org/licenses/by/4.0.

The original article has been corrected.

Open Access This article is licensed under a Creative Commons Attribution 4.0 International License, which permits use, sharing, adaptation, distribution and reproduction in any medium or format, as long as you give appropriate credit to the original author(s) and the source, provide a link to the Creative Commons licence, and indicate if changes were made. The images or other third party material in this article are included in the article's Creative Commons licence, unless indicated otherwise in a credit line to the material. If material is not included in the article's Creative Commons licence and your intended use is not permitted by statutory regulation or exceeds the permitted use, you will need to obtain permission directly from the copyright holder. To view a copy of this licence, visit http://creativecommons.org/licenses/by/4.0/.

Publisher's note Springer Nature remains neutral with regard to jurisdictional claims in published maps and institutional affiliations. 